\title{
Komunikasi Ritual Pembacaan Pengakuan Iman Rasuli dalam Ibadah Gereja Kristen Protestan
}

\author{
Edward Wilianto, Eko Harry Susanto \\ edward.915150115@stu.untar.ac.id,ekos@fikom.untar.ac.id
}

Fakultas Ilmu Komunikasi Universitas Tarumanagara

\begin{abstract}
This research was made as one of the conditions for writers to graduate from the bachelor level of communication science. The author conducted a thesis research on ritual communication in reading the Apostolic Faith in the Worship of the Protestant Christian Church. The author uses several theories as the basis for writing and discussing this research, these theories are ritual communication, transcendental communication, religious communication, and culture. In his discussion the author found several important things regarding the Apostolic Creed and also about the Christian church and its congregation, the church has not provided learning about the meaning of reading the Apostolic Creed, cultural changes that occurred in the Apostolic Creed because of pastoral purposes, and also the relationship of Apostolic Faith with the life of the Christian church..
\end{abstract}

Keywords: Ritual Communication, Apostles Creed, Religious Communication

\begin{abstract}
Abstrak
Penulis melakukan penelitian skripsi mengenai komunikasi ritual dalam pembacaan Pengakuan Iman Rasuli Dalam Ibadah Gereja Kristen Protestan. Penulis menggunakan beberapa teori sebagai landasan untuk menulis dan membahas penelitian ini. Teori tersebut adalah komunikasi ritual, komunikasi transcendental, komunikasi relijius, dan budaya. Dalam pembahasannya penulis menemukan beberapa hal penting mengenai Pengakuan Iman Rasuli dan juga tentang gereja Kristen dan jemaatnya. Gereja belum memberikan pembelajaran mengenai makna dari pembacaan Pengakuan Iman Rasuli, perubahan budaya yang terjadi pada Pengakuan Iman Rasuli karena tujuan pastoral, dan juga keterkaitan Pengakuan Iman Rasuli dengan kehidupan jemaat Kristen.
\end{abstract}

Kata Kunci: Komunikasi Ritual, Pengakuan Iman Rasuli, Komunikasi Religius

\section{Pendahuluan}

Pengakuan iman rasuli sering kali disebut kredo rasuli atau kredo para rasul (the apostle's creed), salah satu dari kredo yang secara luas diterima dan diakui oleh gereja gereja Kristen, khususnya gereja gereja yang berakar dalam tradisi barat. Di kalangan gereja Katholik roma, kredo ini disebut "syahadat para rasul" yang secara pengertian dibagi menjadi tiga bagian yaitu Allah Bapa dan penciptaan, Allah Anak dan penebusan, Allah Roh Kudus dan pengudusan.

Pada awal abad ketiga, pengakuan iman rasuli diucapkan sebagai pengakuan iman seorang pengikut Kristus yang ingin dibaptis. Dalam proses pembaptisan mereka akan dicelupkan ke dalam air sebanyak tiga kali dan setiap kali dicelupkan ke dalam air mereka akan ditanyakan sebuah pertanyaan (Benjamin Myers, 2018:12). 
Pengakuan iman rasuli sekarang dibacakan dalam setiap ibadah Gereja Kristen Protestan. Seiring berjalannya waktu, pengakuan iman rasuli sekarang diucapkan sebagai bentuk komunikasi budaya, namun Pengakuan Iman Rasuli walaupun diucapkan dalam setiap ibadah tapi tidak diberikan pengajaran oleh gereja mengenai makna dari pembacaan Pengakuan Iman Rasuli. Hal ini membuat banyak jemaat Kristen yang memberikan pemaknaan pribadi mereka masing-masing yang menyebabkan pengertian yang salah mengenai Pengakuan Iman Rasuli itu sendiri.

Dalam kasus ini, budaya adalah sesuatu yang diperoleh dan dipertahankan melalui generasi ke generasi. Maka pembacaan iman rasuli yang selalu dibacakan dalam setiap ibadah Gereja Protestan adalah sebuah kebudayaan yang sudah dilakukan dan dipertahankan dari generasi ke generasi. Penulis sendiri juga merasa tertarik untuk melaksanakan penelitian ini karena budaya pembacaan Pengakuan Iman Rasuli adalah salah satu fenomena yang sangat penting bagi jemaat Kristen Protestan sehingga dimasukan sebagai bagian dari tata ibadah atau liturgi.

Perlu diketahui bahwa liturgi atau tata ibadah adalah tata acara yang mengatur bagaimana berjalannya sebuah ibadah dalam suatu gereja yang sudah diatur secara detail sedemikian rupa agar dalam pelaksanaannya liturgi atau tata ibadah akan membentuk sebuah komunikasi dari jemaat kepada Tuhan. Sehingga ketika pembacaan Pengakuan Iman Rasuli dijadikan sebagai bagian dari tata ibadah atau liturgi maka pembacaan Pengakuan Iman Rasuli sendiri sudah menjadi bentuk komunikasi antara jemaat kepada Tuhan.

Dalam pelaksanaannya, pengakuan Iman Rasuli diikrarkan dengan lantang dan ditampilkan teks di dalam slide. Walaupun idealnya jemaat harus menghafal Pengakuan Iman Rasuli, namun kebanyakan jemaat hanya membaca saja teks yang ditampilkan dalam slide. Hal-hal di atas memberikan penulis ketertarikan tertentu mengenai Pengakuan Iman Rasuli, sehingga penulis memutuskan untuk meneliti mengenai Komunikasi Ritual dalam pembacaan Pengakuan Iman Rasuli didalam gereja Kristen Protestan.

\section{Metode Penelitian}

Menurut Taylor dan Bogdan, metodologi kualitatif adalah proses penelitian yang memberikan data - data yang berbentuk kata - kata yang bisa didapatkan melalui subjek - subjek penelitian. Penelitian kualitatif merupakan sebuah budaya dalam ilmu pengetahuan yang secara fundamental bergantung dari pengamatan pada manusia baik dalam wawasannya maupun dalam peristilahannya (Baswori dan Suwandi, 2008:21).

Metode penelitian kualitatif deskriptif merupakan penelitian yang bertujuan untuk memberikan pemahaman mengenai fenomena-fenomena tertentu yang dialami oleh orang - orang misalnya perilaku, persepsi, motivasi, tindakan dan lainya secara keseluruhan dengan cara deskriptif dalam bentuk kata-kata dan bahasa pada suatu konteks tertentu yang alamiah dengan memanfaatkan berbagai metode alamiah (Moleong, 2013:6).

Penelitian yang penulis lakukan bertujuan untuk menganalisis komunikasi ritual pembacaan Pengakuan Iman Rasuli dalam Ibadah Gereja Kristen Protestan, sehingga dalam penelitian ini penulis menggunakan metode pendekatan fenomenologi. Metode ini memungkinkan penulis untuk melakukan pengamatan secara mendalam tentang komunikasi ritual dalam pembacaang Pengakuan Iman Rasuli. 


\section{Hasil Temuan dan Diskusi}

\section{Gereja Belum Memberikan Pembelajaran Mengenai Pengakuan Iman Rasuli.}

Pengakuan Iman Rasuli adalah formulasi iman Kristen yang historis dan sangat berguna untuk membina jemaat Kristen dan juga calon baptisan dalam pengertian akan siapakah Tuhan yang disembah oleh umat Kristen, juga untuk mengingatkan umat Kristen atas identitas mereka, mempersatukan jemaat, dan untuk menyelesaikan polemik/perdebatan. Pengakuan Iman Rasuli yang diucapkan setiap ibadah pada hari minggu sebenarnya lebih menekankan pada pengakuan umat Kristen terhadap identitas mereka sehingga hal ini menunjukan dan menekankan siapakah umat Kristen itu. Pengakuan Iman Rasuli sendiri memiliki tujuan untuk mengingatkan ajaran mendasar mengenai siapakah Tuhan itu sendiri karena didalam Pengakuan Iman Rasuli sendiri terbagi menjadi tiga bagian yang secara jelas memang menggambarkan tentang Allah Tritunggal yaitu Allah Bapa, Allah Anak, Allah Roh Kudus.

Pengakuan Iman Rasuli sendiri adalah sebuah bentuk pengakuan atas identitas umat Kristen sehingga saat mengikrarkan Pengakuan Iman Rasuli sendiri seharusnya tidak terjadi bentuk percakapan antara umat Kristen dengan Tuhan, namun pembacaan Pengakuan Iman Rasuli yang selalu dibacakan dalam setiap ibadah hari minggu adalah bagian dari liturgi atau tata ibadah dari Gereja Protestan. Tata ibadah atau liturgi dirancang sedemikian rupa dengan maksud tertentu dan dalam bentuk komunikasi kepada Tuhan. Sehingga ketika dibacakan maka terjadi percakapan antara umat Kristen dengan Tuhan sebagai bagian dari tata ibadah Gereja Protestan.

\section{Perubahan Ritual Pengakuan Iman Rasuli}

Pengakuan Iman Rasuli pada awal mulanya digunakan hanya dalam upacara pembaptisan bagi anggota-anggota gereja dan tidak diucapkan dalam ibadah setiap minggu. Namun sekarang Pengakuan Iman Rasuli dibacakan dalam ibadah setiap minggu, tapi perlu diketahui bahwa upacara baptisan adalah bagian dari liturgi atau tata ibadah walaupun tidak dilaksanakan setiap minggunya. Seiring berjalannya waktu liturgi atau tata ibadah Gereja Protestan mengalami banyak perkembangan begitu pula dengan bentuk dari Pengakuan Iman Rasuli sendiri. Pengakuan Iman Rasuli membutuhkan waktu sekitar 7 abad untuk disederhanakan menjadi seperti yang ada sekarang ini.

Konsep dari Pengakuan Iman Rasuli harus diucapkan berkali-kali karena Pengakuan Iman Rasuli mengandung konsep yang sangat penting yaitu suatu ajaran mendasar bagi umat Kristen yang menjelaskan mengenai Allah Tritunggal, siapa yang dipercayai, dan juga bagaimanakah pribadi yang dipercayai. Gereja Kristen Protestan mempercayai bahwa tradisi pembacaan Pengakuan Iman Rasuli sangatlah penting bahkan sama seperti doa Bapa Kami dan juga pembacaan 10 Perintah Allah yang juga terus menerus diulang-ulang dalam setiap ibadah karena hal-hal ini akan sangat membantu umat Kristen menyadari siapakah diri mereka, dan siapakah Tuhan mereka, dan bahwa mereka harus menyembah Allah.

\section{Tujuan Pengakuan Iman Rasuli sebagai Pedoman Hidup}

Pengakuan Iman Rasuli adalah bentuk peneguhan bagi umat Kristen yang menyatakan identitas diri mereka, apa yang mereka percaya, dan siapa yang mereka percaya. Sehingga ketika jemaat Kristen datang ke Gereja dan mengikuti alur liturgi 
atau tata ibadah maka mereka akan mendapatkan sebuah peneguhan sehingga ketika mereka pulang dari ibadah mereka memiliki sebuah landasan iman yaitu Pengakuan Iman Rasuli yang menjelaskan siapakah Allah, Allah Yang Maha Kuasa, dan sebagainya, mereka bisa menjalani hidup dengan landasan Iman Rasuli sehingga ketika mereka ada masalah maka mereka dapat mengingat Allah Yang Maha Kuasa tersebut.

Pengakuan Iman Rasuli merupakan sebuah peneguhan iman yang seharusnya dijadikan landasan-landasan iman yang meneguhkan identitas seorang umat Kristen. Pada awalnya Pengakuan Iman Rasuli digunakan untuk menandakan seseorang yang sudah mengikuti berbagai pembelajaran sebagai persiapan untuk dibaptis bahwa sang penerima sakramen baptis adalah seorang murid Kristus sejati. Pengakuan Iman Rasuli sekarang disebutkan dalam setiap ibadah Gereja Protestan dengan tujuan untuk mempersiapkan seseorang untuk menjadi seorang pengikut kristus yang memiliki pengertian dasar mengenai nilai nilai Allah tritunggal.

\section{Simpulan}

1. Di dalam pembacaan Pengakuan Iman Rasuli terdapat makna dan tujuan mengapa perlu diikrarkan dalam setiap ibadah. Makna dan tujuan yang ingin dicapai oleh pembacaan Pengakuan Iman Rasuli adalah untuk mengingatkan dan juga menjadikan nilai - nilai Pengakuan Iman Rasuli sebagai identitas dan pedoman hidup dari umat Kristen.

2. Pengakuan Iman Rasuli pernah mengalami sebuah perubahan budaya, pada awalnya Pengakuan Iman Rasuli digunakan sebagai bentuk pengakuan dan peneguhan dalam upacara baptisan umat Kristen, tapi sekarang Pengakuan Iman Rasuli mengalami perubahan budaya dan sekarang terus dibacakan setiap ibadah hari Minggu, karena sekitar abad 13 gereja sadar akan pentingnya Pengakuan Iman Rasuli sehingga kredo Pengakuan Iman Rasuli disederhanakan dan diikrarkan dalam setiap ibadah di gereja Kristen Protestan

3. Pengakuan Iman Rasuli dibentuk dan disusun berdasarkan ayat - ayat alkitab. Pengakuan Iman Rasuli pada awalnya mengalami perubahan budaya karena gereja menyadari bahwa ada sebuah tujuan penting dalam Pengakuan Iman Rasuli yang sekarang diikrarkan dalam setiap ibadah yaitu Pengakuan Iman Rasuli adalah sebuah dasar - dasar iman dan juga sebuah pedoman hidup bagi seorang umat Kristen sehingga dari pedoman hidup tersebut akan muncul komitmen - komitmen yang diperlukan bagi seorang umat Kristen untuk hidup sesuai alkitab

\section{Ucapan Terima Kasih}

Penulis mengucapkan terima kasih untuk narasumber yang sudah meluangkan waktu sebagai narasumber informasi bagi penulis guna menyelesaikan penelitian dan data-data yang diperlukan sehingga penelitian dapat diselesaikan

\section{Daftar Pustaka}

A. Muri, Yusuf (2014). Metodologi Penelitian Kuantitatif, Kualitatif \& Penelitian Gabungan. Jakarta: Prenadamedia Group

Alo Liliweri. (2011). Komunikasi Serba Ada. Jakarta: Kencana 
Basrowi dan Suwandi. (2008). Memahami Penelitian Kualitatif. Jakarta: Rineka Cipta

Bungin, Burhan. (2010). Metode Penelitian Kualitatif. Jakarta: Rajawali Pers

Dhea Marianti. (2019). "Komunikasi Ritual Tarian Tamborin Dalam Ibadah Raya Gereja Bethel Indonesia di Jakarta".

H.B, Sutopo (2006). Metodologi Penelitian Kualitatif : Dasar teori dan Terapannya dalam Penelitian. Surakarta: Universitas Sebelas Maret

Kezia Natalia. "Studi Komunikasi Ritual Perayaan Ceng Beng di Kota Pontianak"

Khoerunnisa, Rissa dan Yusuf Zaenal Abidin. (2018). Humas: Jurnal Ilmu Hubungan Masyarakat. Jakarta: Salemba.

Kuswarno, Engkus. (2009). Metodologi Penelitian Fenomenolog: Konsepsi, Pedoman, dan Contoh Penelitian. Bandung: Widia Padjajaran

Mischerleen. (2019). “Kucing Hoki Dalam Pandangan Etnis Tionghoa”.

Moleong, Lexy J. (2013). Metode Penelitian Kualitatif. Bandung : PT. Remaja Rosdakarya.

MS Muhajirin. (2016). "Komunikasi Religiusitas Mantan Eks Lokalisasi dan Prostitusi”.

Mulyana, Deddy \& Rakhmat, Jalaluddin. (2006). Komunikasi Antarbudaya:Panduan Berkomunikasi dengan Orang-Orang Berbeda Budaya. Bandung: PT Remaja Rosdakarya

Mulyana, deddy. (1999). Nuansa-Nuansa Komunikasi (Meneropong Politik dan Budaya Komunikasi Masyarakat Kontemporer). Bandung: PT Remaja Rosdakarya.

Mulyana, Deddy. (2005) Ilmu Komunikasi Suatu Pengantar. Bandung: PT Remaja Rosdakarya

Nazir (2011). Metode Penelitian. Bogor: Ghalia Indonesia

Sugiyono. (2016). Metode Penelitian Kuantitatif Kualitataif dan Kombinasi. Bandung: Alfabeta.

Sujarweni, V. Wiratna. (2014). Metode Penelitian: Lengkap, Praktis, dan Mudah Dipahami. Yogyakarta: Pustaka Baru Press

Susanto, Eko Harry (2010). Komunikasi Manusia : Esensi dan Aplikasi Dalam Dinamika Sosial Ekonomi Politik. Jakarta: Mitra Wacana Media.

Susanto, Eko Harry (2018). Komunikasi Manusia : Teori dan Praktik Dalam Menyampaikan Gagasan. Jakarta: Mitra Wacana Media.

Sutrisno, Edy. (2010). Budaya Organisasi. Jakarta: Kencana.

Wayne, R. Pace \& Don, F. Faules. (2010). Komunikasi Organisasi Meningkatkan Kinerja Perusahaan. Bandung: PT Remaja Rosdakarya

West Richard dan Lynn H. Turner. (2008). Pengantar Teori Komunikasi: Analisis Dan Aplikasi. Jakarta: Salemba

Westra, Liuwe. (2002). Instrvmenta Patristica et Mediaevalia: Research on The Inheritance of Early and Medieval Christianity. Belgium: Brepols 